Só o Superior Tribunal de Justiça tem competência para processar e julgar membro de Tribunal Regional do Trabalho em ação, seja qual for sua natureza, pertinente ao exercício de sua função judicante ou administrativa, máxime quando possa resultar em perda do cargo de juiz.

\title{
PARECER
}

\section{OS FATOS}

Sob a alegação de improbidade administrativa, o Ministério Público Federal ajuizou ação civil pública contra juiz e expresidente do Tribunal Regional do Trabalho da $2^{\underline{a}}$ Região perante o Juiz Federal da 12a Vara da Seção Judiciária de São Paulo. Teria havido infração aos artigos 10, I, V, XI e XII, 11, I e II, da lei 8429, de 1992, vertis, "Facilitar ou concorrer por qualquer forma para a incorporação ao patrimônio particular, de pessoa física ou jurídica, de bens, rendas, vertas ou valores integrantes do acervo patrimonial das entidades mencionadas no art. $l^{2}$ desta lei", art. 10, I; "permitir ou facilitar a aquisição, permuta ou locação de bem ou serviço por preço superior ao do mercado", art. 10 , $V$; "liberar verba pública sem a estrita observância das normas pertinentes ou influir de qualquer forma para a sua aplicação irregular", art. 10, XI; "permitir, facilitar ou concorrer para que terceiro se enriqueça ilicitamente", art. 10, XII; "praticar ato visando fim proibido em lei ou regulamento ou diverso daquele previsto na regra de competência". art. 11, I; "retardar ou deixar de praticar, indevidamente, ato de oficio"; art. 11, II. Além de outras sançōes de caráter civil, a lei comina a perda de função pública e a suspensão de direitos políticos de 5 a 8 anos nas infrações descritas no art. 10 e de 3 a 5 anos nas hipóteses do art. 11 . O magistrado se deu por competente para processar e julgar a ação e decretou a indisponibilidade dos bens do demandado. Daí a

\section{CONSULTA:}

membro de Tribunal Regional do Trabalho pode ser processado perante Juiz Federal de primeira instancia em ação da qual possa resultar sua desinvestidura do cargo de juiz ou só o Superior Tribunal de Justiça poderia processálo e julgálo?

\section{PARECER}

1. Segundo regra tradicional em nosso direito constitucional, nenhum juiz pode ser processado e julgado, em matéria penal ou disciplinar, senão por tribunal hierarquicamente superior ou igual a ele, e nunca por juiz a ele inferior. Consagroua a Carta imperial de 1824 , art. 164 , no 2 , reproduzida pela lei de 18 de setembro de 1828 , que organizou o Supremo Tribunal de Justiça, dizendo que a este competia "conhecer dos delitos e erros de oficio que cometerem os seus ministros, os das relações, os empregados no corpo diplomático $e$ os presidentes de províncias". A propósito, observou PIMENTA BUENO: "demais, a ordem ierárquica, as idéias de conveniente subordinação, não permitiam que funcionários tais fossem submetidos ao julgamento de autoridades subalternas", Direito Público Brasileiro, 1857, o 520, pág. 352.

2. Sem soluçāo de continuidade, o princípio vem sendo consagrado nos sucessivos diplomas constitucionais, Constituição de 1824, art. 164, ne 2; Constituição de 1891, art. 57, $\S 2 \mathrm{o}$, lei 221, de 1894, art. 22, I e II; Consti- 
tuição de 1934, art. 76, I, b, c, 104, f; Constituição de 1946, art. 101, I, b, c, 124, IX; Constituiçāo de 1967, art. 114, I, a, b, 136, § 32 , versão de 1969 , art. 119 , I, a, b, 122, I, b, 115, § 30; Constituição de 1988, art. 102, I, b, c, 115, I, a, 108, I, a, 96, III. Podese dizer que o princípio, a despeito de incidentes e acidentes institucionais, integra o patrimônio constitucional do país.

3. Com a criação de tribunais intermediários entre o Supremo Tribunal Federal e os juízes federais e os tribunais estaduais, à mais alta Corte de Justiça ficou reservado processar e julgar, originária e privativamente, seus próprios membros nas infrações penais comuns e os juizes dos tribunais superiores, STJ, TST, TSE, STM, nas infrações penais comuns e nos crimes de responsabilidade, art. 102, I, b, cabendo ao Superior Tribunal de Justiça processar e julgar, originariamente, os desembargadores dos Tribunais de Justiça dos Estados e do Distrito Federal e dos Territórios, os membros dos Tribunais Regionais Federais, dos Tribunais Regionais Eleitorais e dos Tribunais Regionais do Trabalho nos crimes comuns e de responsabilidade, art. 105, I, a, incumbidos os Tribunais Regionais Federais, originariamente, de processar e julgar os juízes federais da área de sua jurisdição, incluídos os da Justiça Militar e da Justiça do Trabalho, nos crimes comuns e de responsabilidade, .... ressalvada a competência da Justiça Eleitoral, art. 108, I, a, cabendo, por fim, aos Tribunais de Justiça julgar os juízes estaduais e do Distrito Federal e Territórios nos crimes comuns e de responsabilidade, ressalvada a competência da Justiça Eleitoral, art. 96, III, todos da Constituição.

\section{DISTINÇÃO NECESSÁRIA}

4. Se se tratasse de questão envolvendo matéria sucessória, ou de família, ou qualquer outra que não dissesse respeito à atuação funcional do magistrado, nem atingisse a garantia constitucional da vitaliciedade, não hesitaria em proclamar a competência do mm. Juiz da Vara Federal da Seção Judiciária de São Paulo, mas, envolvendo, como envolve, o magis- trado em sua condição e atuação de magistrado, que. procedente a ação, verseá desquitado de seu cargo vitalício de juiz, sinto necessidade de examinar o problema à luz dos princípios constitucionais que informaram no passado e informam no presente a organização judiciária do país, tanto mais quando a Constituição nāo contém norma quanto à ação e procedimento derivados do $\S 4$, do seu art. 37 , por ela introduzido em nossa legislação, verbis, "os atos de improbidade administrativa importarão a suspensão dos direitos políticos, a perda da função pública, a indisponibilidade dos bens e o ressarcimento ao erário, na forma e graduaçāo previstas em lei, sem prejuízo da ação penal cabível".

5. O texto legal anterior que dele mais se aproxima é o art. 151, da Carta de 1967, "aquele que abusar dos direitos individuais previstos nos $\$ \S 8$ \& 23,27 e 28 do artigo anterior e dos direitos políticos, para atentar contra a ordem democrática ou praticar a corrup̧̧ão, incorrerá na suspensão destes últimos direitos pelo prazo de dois a dez anos, declarada pelo Supremo Tribunal Federal, mediante representação do ProcuradorGeral da República, sem prejuizo da ação cível ou penal cabiveis, assegurada ao paciente a mais ampla defesa". A versāo de 1969, art. 154, era deste teor: "o abuso de direito individual ou político, com o propósito de subversão do regime democrático ou de corrupção, importará a suspensão daqueles direitos de dois a dez anos, a qual será declarada pelo Supremo Tribunal Federal, sem prejuizo da ação civel ou penal que couber, assegurada ao paciente ampla defesa. Parágrafo único. Quando se tratar de titular de mandato eletivo, o processo não dependerá de licença da Câmara a que pertencer". Como se vê, nem de longe os preceitos se equiivalem, havendo apenas semelhança e distante.

6. Mas, seja qual for o alcance que se der ao $\S 44^{\circ}$, do art. 37 , da Constituição, todo ele endereçado à administração pública, não se lhe pode atribuir sentido conflituoso com princípios historicamente consagrados e reafirmados pela mesma Constituição, que não admite preceitos contraditórios, princípios amalgamados no pecúlio consolidado do di- 
reito constitucional pátrio, desde a Carta de 1824, e segundo o qual se não admite que membro de um tribunal, em assunto funcional, possa ser processado e julgado por juiz de menor hierarquia.

\section{PARALELISMO INEGÁVEL}

7. Dirseá que as normas constitucionais arroladas referemse a matéria penal e a lei 8429 não é de natureza criminal. É de lembrarse, todavia, que o mesmo princípio vige em matéria disciplinar e a este a Constituição se não refere, senão implicitamente.

8. É inegável o paralelismo entre as infraçōes desenhadas na lei 8429 e as descritas nos artigos 312,319 e 315 , do Código Penal, peculato, prevaricação e emprego irregular de verbas públicas, assim como as sançōes indicadas na Constituição, art. 15, III e V, 37, § 40, se não distinguem do que estabelece o Código Penal, art. 92, I, "são também efeitos da condenação: a perda do cargo, função pública ou mandato eletivo, nos crimes praticados com abuso de poder ou violação de dever para com a Administração Pública quando a pena aplicada for superior a quatro anos".

9. Não serão de natureza penal as sançōes estipuladas na lei 8.429 , inspirada no $\S 4^{2}$ do art. 37, da Constituição, mas elas chegam a superporse aos preceitos do Código Penal, tão íntimo é o seu parentesco. É inegável, há real justaposiçāo de sanções cominadas em ambas as leis, a despeito de sua distinta natureza.

10. Mas, mesmo reconhecendo que os preceitos constitucionais invocados, da Constituição e dos diplomas anteriores, referemse a infrações penais, e tanto a Constituição no $\S$ $4^{\circ}$ do seu art. 37, como a lei 8.429, art. 12, deixem expresso que as sançōes cominadas em casos de improbidade não excluem ação penal, nem por isso poderia um juiz sujeitarse, em assunto que envolvesse seu status de magistrado, a ser processado e julgado por juiz de menor hierarquia, sem ofensa frontal ao sistema constitucional relativo à ordem, estrutura, disciplina e hierarquia judiciária, aos seus princípios explícitos e implícitos.

Paulo Brossard, advogado
11. Tenho como incontroverso que um membro de tribunal, seja ele qual for, federal ou estadual, em assunto referente à sua atuação funcional, nāo pode ser processado e julgado por juiz de inferior posição hierárquica. Este o ponto nuclear da questão.

\section{CONSTRUÇÃO NECESSÁRIA}

12. Em verdade, o fato de a Constituição falar apenas em infrações penais ou em crimes comuns e de responsabilidade nāo encerra a questão. Seria prestar homenagem exagerada à literalidade das expressōes, fórmula cômoda, mas perigosa. A questão, que é relevante, não pode enterreirarse em limites tão estreitos. Parece claro que se está em face de lacuna visível, a reclamar a inafastável e apropriada construçāo constitucional, técnica que nenhuma lei, em princípio, pode desprezar, e muito menos a lei constitucional.

13. "Em qualquer lei, (escreveu RUI BARBOSA), por mais circunstanciativos que sejam os seus termos, considerável é sempre, debaixo da matéria explicita, a matéria não expressa, que se lhe tem de subentender por ilação". "Nas constituições, de mais a mais, o elemento implícito assume proporções, sem comparação, mais inevitáveis, mais relevantes e mais vastas do que nas leis ordinárias; porquanto, ao passo que as leis ordinárias são mais ou menos regulamentares, decompõem com mais ou menos miudezas os assuntos, de que tratam, a constituição apenas descreve linhas gerais, e só assinala os grandes traços da organização do pais", Questão Minas Werneck. Competencia do Supremo Tribunal Federal nas apelações de sentenças arbitrais, 1917, ne 31 e 29, pág. 35 e 33.

14. Aliás, não será a primeira vez que a Constituição, nāo tendo dado solução explícita a determinado problema, reclame a apropriada construção constitucional para extrair de seus princípios imanentes, quando nāo expressos, a seqüência lógica indispensável ao seu pleno cumprimento. 


\section{PRECEDENTES ILUSTRATIVOS}

15. Em nossa experiência constitucional, em verdade, nāo faltam precedentes ilustrativos, tanto mais quando ligados à competência originária do Supremo Tribunal Federal.

16. O primeiro deles ocorreu logo depois de promulgada a Constituição de 1891. Então, como agora, cabia ao Senado julgar "os membros do Supremo Tribunal Federal nos crimes de responsabilidade, e este os juizes federais inferiores", art. $57, \S 2^{\circ}$, nada dizendo a respeito de crimes comuns, fossem de ministros do Supremo Tribunal Federal, fossem de juízes federais. A lacuna era visível. Não foi difícil suprila. Nunca se duvidou de que só o Supremo Tribunal Federal deveria ter o intransferível encargo de processar e julgar uns e outros. Foi nesse sentido a construção feita pelo próprio Supremo Tribunal Federal ao editar seu Regimento Interno, art. $15, \S 1 \stackrel{1}{a} a$ e $d$, como foi a do Congresso ao elaborar a lei 221 , de 1894 , art. 22, I e II. E na mesma linha o entendimento da doutrina, BARBALHO, Constituição Federal, 1902, pág. 233; MAXIMILIANO, Comentários, 1929, n² 379, pág. 610; ARAUJO CASTRO, Manual da Constituição Brasileira, 1920, pág. 150; RODRIGO OCTAVIO e PAULO VIANNA, Direito Público e Constitucional, 1930, pág. 257; PONTES DE MIRANDA, Comentários à Constituição Federal de 1934, s.d., I, pág. 649.

17. Poderseia dizer que, nesse caso, a lei veio a sanar a lacuna. Pouco importa, a lacuna foi reconhecida e suprida em honra da Constituiçāo. Mas a nossa história constitucional registra outro caso, ocorrido um quarto de século mais tarde, e igualmente ilustrativo, em que a doutrina apontou a lacuna e a solução e o Supremo Tribunal Federal, construtivamente, a chancelou. Curiosamente, o caso guarda viva semelhança com a situação em exame.

18. Nos termos do art. 59, II, da primeira Constituição republicana, de decisões de juízes e tribunais federais cabia recurso para o Supremo Tribunal Federal. Nāo dizia, porém, uma palavra acerca de decisōes proferidas em juízos arbitrais. De uma decisão arbitral, envolvendo o Estado de Minas Gerais, RUI
BARBOSA apelou para o Supremo Tribunal Federal e este conheceu e julgou o recurso.

19. Da quase esquecida monografia " $\mathrm{Com}$ petência do Supremo Tribunal Federal nas apelações de sentenças arbitrais" é esta passagem, que parece escrita para o caso em exame:

“31. Em qualquer lei, por mais circunstanciativos que sejam os seus termos, considerável é sempre, debaixo da matéria explicita, a matéria não expressa, que se lhe tem de subentender por ilaçāo.

"Cada lei", dizem os mestres americanos, "cada lei se supõe conter implicitamente, quando o não contém nas suas formais palavras, todas as disposições, que necessárias sejam, para dar realidade ao seu propósito e objeto, ou para dar efetividade aos direitos, aos poderes, aos privilégios, ou às jurisdições, que ela institui, bem como todas as consequências colaterais ou subsidiárias, que dos seus termos se possam, justa e logicamente, inferir".

Campbell Black, Construction and Interpretation of the Laws, $\mathrm{n}^{2} 33$, pág. 62 .

32. Mas, se, no entender e aplicar as próprias leis ordinárias, até ai vai o trabalho construtor da inferência, bastaria admitir que só até ai vá, que não se estenda, como se estende, muito além, a legitima ação do processo ilativo na inteligência e aplicação das leis constitucionais, bastaria isto, para se não poder contestar que, em cada Constituição, à luz do critério imposto aos seus hermenêutas e executores, lado a lado com as determinações textuais, se hão de ter por existentes, como disposiçōes inexpressas, todas as regras, todas as exigências, todos os corolários essenciais à realidade ativa de quaisquer instituições ou direitos, de quaisquer autoridades ou prerrogativas, de quaisquer jurisdições ou magistraturas, consagradas nessa Constituição, e que, se ela articula normas positivas, tão imperativas, quanto essas fórmulas declaradas são as que, implícitas nestas, subsidiária ou colateralmente delas decorrerem.

É o que nos ensina a lição do exímio constitucionalista americano pouco há citado $\left(\mathrm{n}^{\mathcal{Q}}\right.$ 31 ), condensando num breve e incisivo enunciado uma noção elementar em matéria de 
interpretação legislativa e constitucional: a noção de que. se o texto reconhece um direito. confere um poder, outorga um privilégio, ou cria uma jurisdição. - no que a letra dispõe, subentendido está que o seu animo dispōe tudo quanto necessário seja. para tornar real esse direito, para tomar eficaz esse poder, para tomar seguro esse priviléglo, para tornar cabal essa jurisdição. quer se trate de considerar a jurisdição, o priviléglo, o direito, o poder, no que constitui a substancia de cada um deles, quer de verificar o que da existência de cada um deles se deduza, ainda que subsidiária ou colateralmente," op. cit., pág. 35 a 37.

\section{A CONSTITUIÇĀO NĀO É ALEIJADA}

20. De modo que mesmo se não dê interpretaçāo extensiva ao art. 105, I, a, da Constituição, por tratarse de competência, como já sustentado, e a despeito do paralelismo entre os ilícitos penais e não penais, descritos na lei 8429 e no Código Penal, comparadas as respectivas sanções, seria inevitável fosse a lacuna suprida mediante a necessária construção, a menos se preferisse romper com o sistema constitucional, consagrado de 1824 a 1988 , para permitir que ação ajuizada contra membro de Tribunal Regional do Trabalho fosse processada e julgada por juiz hierarquicamente inferior, em feito que, embora sem natureza penal, virtualmente acarretaria a perda de cargo vitalício e suspensão de direitos políticos, além de outras sanções, envolvendo direta e imediatamente sua condição de magistrado.

21. Não se trata de privilégio pessoal, desnecessário será dizêlo, mas de norma indisponível de direito objetivo, inerente à posição de cada juiz na nomenclatura do Poder Judiciário.

\section{HIPÓTESE ESCLARECEDORA}

22. A prevalecer a solução em exame, ter- seia de admitir que até um Ministro do Supremo Tribunal Federal poderia vir a ser processado e julgado com fundamento na lei 8429 por juiz federal de primeira instância e vir a ser despojado do cargo vitalício de membro da mais alta Corte da Nação, à revelia dela, pois a questão, envolvendo fundamentalmente matéria de prova, encerrarseia normalmente em Tribunal Regional Federal, art. 108, II, da Constituição. E quando o desfecho da ação fosse absolutório, as consequiências pessoais, funcionais e institucionais seriam inapagáveis e irreparáveis.

\section{NULIDADE}

23. A meu juízo, a ação encetada perante a $12^{\mathrm{a}}$ Vara da Justiça Federal da Seção Judiciária de São Paulo é irremediavelmente nula, dada a incompetência absoluta do magistrado que a recebeu, em detrimento da competência do Superior Tribunal de Justiça.

\section{CONCLUSĀO}

24. Pelo exposto, sou de parecer que membro de Tribunal Regional do Trabalho, em tema pertinente ao exercício de suas funções judicantes ou administrativas, envolvendo mesmo sua permanência na magistratura ou o seu afastamento dela, nāo pode ser processado e julgado por juiz a ele hierarquicamente inferior.

Só o Superior Tribunal de Justiça seria competente para processar e julgar ação, seja de que natureza for, desde que de molde a atingir o juiz como juiz e enquanto Juiz, com a agravante de trazer em si, virtualmente, o divórcio do magistrado com o Poder Judiciário.

E o meu parecer.

Porto Alegre, 5 de abril de 1999.

Paulo Brossard de Souza Pinto, Ministro aposentado do Supremo Tribunal Federal 